\title{
Pengaruh Suhu dan Waktu Penyangraian Terhadap Aktivitas Antioksidan dan Sifat Sensoris Kopi Tiruan Biji Pepaya (Carica papaya L.)
}

\section{Effect of Temperature and Roasting Time on the Antioxidant Activity and Sensory Properties of Artificial Coffee Papaya Seeds (Carica papaya L.)}

\author{
Najmudin $^{1}$, I Made Sugitha ${ }^{{ }^{*}}$, I Desak Putu Kartika Pratiwi ${ }^{1}$ \\ Program Studi Teknologi Pangan, Fakultas Teknologi Pertanian, Universitas Udayana \\ Kampus Bukit Jimbaran, Badung-Bali \\ *Penulis korespondensi: I Made Sughita, Email: madesugitha@unud.ac.id
}

\begin{abstract}
This Study aims to determine the effect of temperature and roasting time on antioxidant activity and sensory properties of artificial coffee papaya seeds to produce papaya seeds coffee with high antioxidant activity and the best sensory properties. The experimental design used in this study was a Factorial Completely Randomized Design which were the first factor is the roasting temperature $\left(80^{\circ} \mathrm{C}, 90^{\circ} \mathrm{C}, 100^{\circ} \mathrm{C}\right)$ and the second factor is the roasting time (5 minutes, 10 minutes, 15 minutes). The treatment was repeated 2 times to obtain 18 experimental units. The data was analyzed with analysis of variance and if the treatment had a significant effect, then followed by Duncans Multiple Range Test. The parameters tested in this study included moisture content, total phenol, total flavonoid, qualitative caffeine, antioxidant activity and sensory properties. The results showed that papaya coffee seeds with a temperature of $100^{\circ} \mathrm{C}$ and roasting time of 10 minutes were the best treatment with water content value of $3.76 \%$, total phenol $1.25 \mathrm{mgGAE} / \mathrm{g}$, total flavonoids $0.29 \mathrm{mgQE} / \mathrm{g}$, antioxidant activity $24.03 \%$, caffeine (qualitative) negative with sensory properties color was yellowish-brown, aroma was distintive of papaya seeds, taste was bitter, and overall acceptance was liked.
\end{abstract}

Keywords: antioxidant activity, artificial coffee, papaya seeds, sensory properties, roasting temperature, roasting time

\section{PENDAHULUAN}

Minuman kopi tiruan merupakan inovasi pembuatan minuman kopi dari biji-bijian yang memiliki sifat sensoris warna, rasa dan aroma hampir sama dengan kopi asli. Minuman kopi tiruan dapat bermanfaat bagi seseorang yang memiliki toleransi rendah terhadap kafein maupun bagi seseorang yang tidak dapat mengkonsumi kafein (Wahyu, 2002). Kadar kafein yang tinggi didalam biji kopi diduga akan menyebabkan beberapa keluhan kesehatan, terutama bagi penikmat kopi yang memiliki toleransi rendah terhadap kafein seperti insomnia, kecemasan, peningkatan tekanan darah dan detak jantung yang lebih cepat (Ogita et al., 2003). Kopi yang mengandung kafein tinggi apabila dikonsumsi secara berlebihan maka akan berbahaya bagi kesehatan tubuh, sehingga berdasarkan hal tersebut munculah inovasi pembuatan minuman kopi tiruan yang berasal dari biji-bijian lainnya.

Salah satu biji-bijian yang dapat dimanfaatkan untuk pembuatan kopi tiruan adalah 
biji pepaya. Biji pepaya merupakan salah satu bijibijian yang kurang dimanfaatkan oleh masyarakat karena memiliki rasa yang pahit, pedas dan beraroma menyengat sehingga biji pepaya masih dianggap limbah oleh masyarakat dan belum dimanfaatkan secara optimal. Biji pepaya mengandung dua senyawa kimia yaitu golongan polifenol dan fenol yang bermanfaat baik bagi kesehatan, golongan polifenol yang terdapat pada biji pepaya terdiri dari senyawa saponin dan tanin sedangkan golongan fenol yang terdapat pada biji pepaya terdiri dari senyawa flavonoid yang menyebabkan biji pepaya terasa pahit dan berperan sebagai antioksidan (Andriani et al., 2016). Biji pepaya bermanfaat sebagai antioksidan melalui zat fitokimia yang dikandungnya yaitu meliputi flavonoid, saponin, dan tannin (Agustina et al., 2013). Biji pepaya merupakan salah satu biji-bijian yang tidak mengandung kafein sehingga dapat dimanfaatkan sebagai kopi tiruan non kafein pengganti biji kopi. Biji pepaya memiliki rasa yang pahit dan apabila disangrai akan menghasilkan bubuk biji pepaya dengan aroma, warna yang mendekati kopi asli (Mariati, 2015). Biji pepaya dapat diolah menjadi minuman kopi yang baik untuk kesehatan terutama dalam pengobatan hiperlipidemia dengan proses pengolahan yang benar (Erlinda dan Fenti 2015).

Proses pengolahan kopi terdiri dari beberapa tahap yaitu tahap pengeringan, pengupasan kulit, penyangraian, pendinginan dan penggilingan menjadi kopi bubuk (Hamni dan Arinal 2014). Penyangraian (roasting) merupakan kunci dari tahapan produksi kopi (Nugroho, 2009). Menurut penelitian Utami (2016) semakin tinggi suhu dan lama penyangraian, maka aktivitas antioksidan yang diperoleh semakin kecil. Menurut penelitian Annisa (2016) melaporkan bahwa kopi bubuk non kafein dari biji pepaya dan buah nangka dengan lama penyangraian 12 menit menghasilkan aktivitas antioksidan sebesar 95,61\% dengan suhu dibawah $100^{\circ} \mathrm{C}$

Penelitian mengenai suhu dan waktu penyangraian biji pepaya yang lebih spesifik tanpa menggunakan bahan tambahan belum pernah dilaporkan. Berdasarkan hal tersebut, didasari karena adanya kandungan senyawa bioaktif dari biji pepaya dan pemanfaatannya yang kurang maksimal, maka perlu dilakukan penelitian pengaruh suhu dan waktu penyangraian biji pepaya yang bertujuan untuk mengetahui pengaruh suhu dan waktu penyangraian serta menentukan suhu dan waktu penyangraian terbaik untuk menghasilkan kopi tiruan biji pepaya dengan aktivitas antioksidan dan sifat sensoris terbaik.

\section{METODE PENELITIAN}

\section{Tempat dan Waktu Penelitian}

Penelitian ini dilaksanakan di Laboratorium Ekofisiologi dan Fitopatologi, Gedung Laboratorium Terpadu, Balai Penelitian Tanaman 
Industri dan Penyegar (BALITTRI), Jalan Raya Pakuwon Km. 2 Parungkuda, Sukabumi Jawa Barat. 43357. Penelitian ini dilaksanakan pada bulan Agustus 2020 sampai dengan bulan September 2020 .

\section{Bahan dan Alat}

Bahan yang digunakan dalam penelitian ini adalah biji pepaya berwarna hitam jenis california yang diperoleh dari penjual buah pepaya di Desa Kalapa Nunggal, Kabupaten Sukabumi, Jawa Barat dan bahan-bahan kimia seperti 2,2-diphenyl-1picrylhidrazyl (DPPH) (Himedia), reagen FolinCiocalteu (merck), Methanol PA 100\% (merck), standar asam galat (merck), $\mathrm{Na}_{2} \mathrm{CO}_{3}$ (merck), $\mathrm{AlCl}_{3}$, standar kuersetin (sigma), kobalt nitrat, dan ammonia encer yang diperoleh dari CV. Chem-Mix Pratama, Yogyakarta.

Alat yang digunakan pada penelitian ini yaitu roaster mini, pisau, corong kaca, oven (JP. Selecta 2005141), blender (Philips), timbangan analitik (Kern $A B J)$, spatula, alumunium foil, gelas ukur (Iwaki), erlenmeyer (Pyrex), botol gelap, gelas beaker (Iwaki), spektrofotometer (Genesys 10s Uvvis), kufet kaca, pipet volume (Pyrex), pipet tetes, pipet mikro (Thermo scientific), vortex (Labnet), tabung reaksi (Pyrex), tabung sentrifuge (Iwaki), sentrifuge (Fleta -5), labu ukur $50 \mathrm{ml}$ (Pyrex), labu ukur $100 \mathrm{ml}$ (Pyrex) dan hetjet (Thermo scientific).

\section{Rancangan Penelitian}

Penelitian ini menggunakan Rancangan acak lengkap (RAL) pola faktorial dengan 2 faktor, yaitu suhu penyangraian dan waktu penyangraian.
Faktor I: Suhu penyangraian, terdiri dari 3 taraf yaitu:

$\mathrm{T} 1=80^{\circ} \mathrm{C}$

$\mathrm{T} 2=90^{\circ} \mathrm{C}$

$\mathrm{T} 3=100^{\circ} \mathrm{C}$.

Faktor II: Waktu penyangraian, terdiri dari 3 taraf yaitu:

$\mathrm{L} 1=5$ menit;

$\mathrm{L} 2=10$ menit;

L3 = 15 menit

Masing-masing kombinasi perlakuan diulang sebanyak 2 kali sehingga diperoleh 18 unit percobaan. Data yang diperoleh dianalisis menggunakan sidik ragam atau Analysis of Variance (ANOVA). Apabila dari hasil uji tersebut terdapat pengaruh maka dilanjutkan dengan uji Duncan's Multiple Range Test (DMRT) menggunakan IBM SPSS Statistics 25 dengan selang kepercayaan 95\% (Gomez dan Gomez, 1995).

\section{Pelaksanaan Penelitian}

Tahap pelaksanaan penelitian meliputi dua tahap yaitu tahap pembuatan bubuk kopi tiruan biji pepaya dan tahap pembuatan seduhan kopi untuk uji sensoris.

\section{Proses Pembuatan Bubuk Kopi Tiruan Biji Pepaya}

Pembuatan kopi tiruan biji pepaya diawali dengan proses pemilihan biji yang berwarna hitam dari pepaya yang telah matang. Selanjutnya biji pepaya dicuci menggunakan air mengalir dan ditiriskan, kemudian dilakukan pengeringan sinar 
matahari selama 3 jam untuk mengurangi kadar air pada biji pepaya. Setelah kering ditimbang $200 \mathrm{~g}$ biji pepaya kemudian dilakukan penyangraian menggunakan mini roaster dengan suhu dan waktu penyangraian sesuai perlakuan. Kemudian biji yang telah disangrai dihaluskan menggunakan grinder kopi atau blender sampai halus.

\section{Proses Pembuatan Seduhan Kopi Tiruan Biji Pepaya}

Pembuatan seduhan kopi dilakukan dengan teknik Drip Brewing V60 yaitu teknik penyeduhan kopi menggunakan alat berupa corong gelas seperti $\mathrm{V}$ dengan kemiringan 60 derajat. Teknik penyeduhan ini dilakukan dengan cara ditimbang bubuk Kopi tiruan biji pepaya sebanyak $10 \mathrm{~g}$, kemudian tuangkan pada V60 yang sudah dilapisi filter atau kertas saring dan diseduh dengan air panas $150 \mathrm{ml}$, suhu $\pm 90^{\circ} \mathrm{C}$ selama $\pm 1,5$ menit dengan gerakan memutar untuk menghasilkan rasa kopi teraduk secara sempurna (Gardjito dan Rahardian, 2011).

\section{Variabel yang diamati}

Variabel yang diamati dalam penelitian ini adalah kadar air diukur dengan metode pengeringan (Sudarmadji et al, 1997).

Total fenol menggunakan metode folin-ciocalteu (Sakanaka et al., 2003), total flavonoid menggunakan metode spektrofotometri (Rahman et al., 2006), aktivitas antioksidan menggunakan metode 2,2-diphenyl-1-picrylhidrazyl (DPPH) (Blois, 1958 dalam Hanani et al., 2005), uji kafein secara kualitatif menggunakan metode parry (Maramis, 2013) dan sifat sensoris warna, aroma, rasa, dan penerimaan keseluruhan (Soekarto, 1985).

\section{HASIL DAN PEMBAHASAN}

\section{Hasil Analisis Bahan Baku}

Nilai rata-rata kadar air, total fenol, total flavonoid, dan aktivitas antioksidan biji pepaya dapat dilihat pada Tabel 1.

Tabel 1. Hasil analisis bahan baku biji pepaya

\begin{tabular}{cc}
\hline Variabel & Jumlah \\
\hline Kadar Air (\% bb) & 69,98 \\
Total Fenol (mg GAE/g) & 0,89 \\
Total Flavonoid (mg QE/g) & 0,23 \\
Aktivitas Antioksidan (\% bb) & 41,85 \\
\hline
\end{tabular}

\section{Hasil Analisis Kimia Kopi Tiruan Biji Pepaya}

Nilai rata-rata kadar air kopi tiruan biji pepaya dengan perlakuan suhu dan waktu penyangraian dapat dilihat pada Tabel 2, total fenol kopi tiruan biji pepaya dapat dilihat pada Tabel 3, total flavonoid kopi tiruan biji pepaya dapat dilihat pada Tabel 4, aktivitas antioksidan kopi tiruan biji pepaya dapat dilihat pada Tabel 5, dan analisis kafein secara kualitaif kopi tiruan biji pepaya dapat dilihat pada Tabel 6. 


\section{Kadar Air}

Nilai rata-rata kadar air kopi tiruan biji pepaya dengan perlakuan suhu dan waktu penyangraian dapat dilihat pada Tabel 2.

Hasil sidik ragam menunjukkan bahwa interaksi antara suhu dan waktu penyangraian tidak berpengaruh nyata $(\mathrm{P}>0,05)$ terhadap kadar air kopi tiruan biji pepaya. Perlakuan suhu penyangraian tidak berpengaruh nyata $(\mathrm{P}>0,05)$ terhadap kadar air kopi tiruan biji pepaya sedangkan waktu penyangraian berpengaruh nyata $(\mathrm{P}<0,05)$ terhadap kadar air kopi tiruan non kafein biji pepaya. Nilai rata-rata kadar air kopi tiruan biji pepaya berkisar antara 3,39\% - 3,94\% dengan nilai ata-rata kadar air terendah yaitu T3L3 sebesar 3,39\% dan kadar air tertinggi yaitu T1L1 sebesar 3,94\% (Tabel 2). Nilai kadar air menurun seiring dengan meningkatkanya waktu penyangraian dari biji pepaya. Waktu penyangraian 15 menit menghasilkan kadar air terendah yaitu 3,39\%. Peningkatan waktu penyangraian secara signifikan menurunkan kadar air dari kopi tiruan biji pepaya. Kadar air terendah dihasilkan pada perlakuan T3 dengan waktu penyangraian 15 menit. Semakin lama dilakukannya penyangraian maka akan mempengaruhi nilai kadar air pada kopi tiruan biji pepaya. Kadar air kopi tiruan biji pepaya cenderung mengalami penurunan pada saat suhu dan lama penyangraian mengalami peningkatan. Hal tersebut sesuai dengan pernyataan Estiasih dan Ahmadi
(2009), bahwa semakin besar perbedaan suhu antara medium pemanas dengan bahan pangan semakin cepat pindah panas ke bahan pangan dan semakin cepat pula penguapan air dari bahan pangan. Perubahan massa air akan terjadi ketika kandungan air pada bahan telah sampai pada kondisi jenuh, sehingga menyebabkan air yang terkandung didalam biji papaya berubah dari fase cair menjadi uap.

Kadar air kopi tiruan non kafein biji pepaya menurun seiring dengan meningkatnya waktu penyangraian yang digunakan, tetapi tidak terjadi interaksi antara waktu dan suhu penyangraian terhadap kadar air. Hal ini dipengaruhi oleh tingginya kadar air pada biji pepaya, dan juga suhu penyangraian yang digunakan tidak memberikan pengaruh yang signifikan terhadap kadar air kopi tiruan biji papaya. Kadar air suatu produk ditentukan oleh kadar air bahan baku dan penunjang yang digunakan, selain itu dipengaruhi juga oleh proses pengolahan (Bactiar et al., 2017).

Kandungan air di dalam bahan pangan memiliki peranan yang sangat penting karena dapat menentukan kualitas produk dan sangat berpengaruh terhadap umur simpan bahan pangan (Praseptiangga et al., 2016). Nilai rata-rata kadar air dari semua perlakuan telah memenuhi syarat mutu kopi sangrai yaitu maksimal 4\% b/b (SNI. 01-2983-1992) dan syarat mutu kopi bubuk (SNI 01-3542:2004) yaitu maksimal 7\%. 
Tabel 2. Nilai rata-rata kadar air (\%bb) kopi tiruan biji papaya dengan perlakuan suhu dan waktu penyangraian

\begin{tabular}{ccccc}
\hline Suhu & \multicolumn{3}{c}{ Waktu Penyangraian } \\
Penyangraian & L1 (5 Menit) & L2 $(10$ Menit $)$ & L3 $(15$ Menit $)$ & Rata-rata \\
\hline T1 $\left(80^{\circ} \mathrm{C}\right)$ & $3,94 \pm 0,50$ & $3,86 \pm 0,25$ & $3,50 \pm 0,19$ & $3,77 \mathrm{a}$ \\
T2 $\left(90^{\circ} \mathrm{C}\right)$ & $3,93 \pm 0,22$ & $3,85 \pm 0,36$ & $3,48 \pm 0,09$ & $3,75 \mathrm{a}$ \\
T3 $\left(100^{\circ} \mathrm{C}\right)$ & $3,89 \pm 0,32$ & $3,76 \pm 0,48$ & $3,39 \pm 0,04$ & $3,68 \mathrm{a}$ \\
Rata-rata & $3,92 \mathrm{a}$ & $3,83 \mathrm{ab}$ & $3,45 \mathrm{~b}$ & \\
\hline
\end{tabular}

Keterangan: Nilai rata-rata \pm standar deviasi. Huruf yang sama dibelakang nilai rata-rata pada kolom dan baris yang sama menunjukkan berbeda tidak nyata $(\mathrm{P}>0,05)$.

Tabel 3. Nilai rata-rata total fenol (mg GAE/g) kopi tiruan biji pepaya dengan perlakuan suhu dan waktu penyangraian.

\begin{tabular}{cccc}
\hline Suhu & \multicolumn{3}{c}{ Waktu Penyangraian } \\
\cline { 2 - 4 } Penyangraian & L1 (5 Menit) & L2 (10 Menit) & L3 (15 Menit) \\
\hline T1 $\left(80^{\circ} \mathrm{C}\right)$ & $\begin{array}{c}0,60 \pm 0,01 \mathrm{~b} \\
\text { (a) }\end{array}$ & $\begin{array}{c}0,63 \pm 0,05 \mathrm{c} \\
\text { (a) }\end{array}$ & $\begin{array}{c}0,77 \pm 0,12 \mathrm{~b} \\
\text { (a) }\end{array}$ \\
$\mathrm{T} 2\left(90^{\circ} \mathrm{C}\right)$ & $0,78 \pm 0,10 \mathrm{~b}$ & $0,99 \pm 0,03 \mathrm{~b}$ & $0,78 \pm 0,08 \mathrm{~b}$ \\
& $(\mathrm{a})$ & $(\mathrm{a})$ & $(\mathrm{a})$ \\
$\mathrm{T} 3\left(100^{\circ} \mathrm{C}\right)$ & $1,03 \pm 0,03 \mathrm{a}$ & $1,25 \pm 0,05 \mathrm{a}$ & $1,23 \pm 0,07 \mathrm{a}$ \\
& $(\mathrm{b})$ & (a) & (a) \\
\hline
\end{tabular}

Keterangan: Nilai rata-rata \pm standar deviasi. Huruf yang sama dibelakang nilai rata-rata pada kolom yang sama dan dibawah nilai rata-rata pada baris yang sama menunjukkan berbeda tidak nyata $(\mathrm{P}>0,05)$.

\section{Total Fenol}

Nilai rata-rata total fenol kopi tiruan biji pepaya dengan perlakuan suhu dan waktu penyangraian dapat dilihat pada Tabel 3 . Hasil sidik ragam menunjukkan bahwa interaksi antara suhu dan waktu penyangraian berpengaruh nyata $(\mathrm{P}<0,05)$ terhadap total fenol kopi tiruan biji pepaya. Hasil penelitian menunjukkan total fenol biji pepaya segar yaitu sebesar $0,89 \mathrm{mgGAE} / \mathrm{g}$. Nilai rata-rata total fenol kopi tiruan biji pepaya berkisar antara 0,60$1,25 \mathrm{mgGAE} / \mathrm{g}$ dengan total fenol terendah yaitu T1L1 sebesar 0,60 mgGAE/g dan total fenol tertinggi yaitu T3L2 sebesar 1,25 mgGAE/g (Tabel 3).
Suhu dan waktu penyangraian berpengaruh signifikan terhadap total fenol kopi tiruan biji pepaya. Pada perlakuan T1L1, T1L2, T1L3, T2L1 dan T2L2 total fenol terus meningkat dan mengalami penurunan kembali pada perlakuan T2L3 dan T3L3. Perlakuan T1L1 menghasilkan total fenol terendah yaitu sebesar 0,60 mgGAE/g. Hal ini bisa disebabkan karena rendahnya suhu dan waktu yang digunakan pada saat proses penyangraian, sehingga senyawa-senyawa yang terdapat pada biji pepaya belum terurai secara sempurna. Menurut penelitian yang dilakukan oleh Nindyasari (2012) menyatakan bahwa waktu pemanasan yang terlalu singkat menyebabkan 
kelarutan senyawa pada bahan belum mencapai titik yang optimal serta menyebabkan senyawa fenolik belum terurai secara sempurna.

Pada dasarnya suhu dan lama pemanasan yang tinggi akan menyebabkan kandungan total fenol yang semakin tinggi pula (Wazir et al., 2011) akan tetapi pada penelitian ini kandungan total fenol menurun setelah dilakukan penyangraian selama 15 menit pada suhu $90^{\circ} \mathrm{C}$ dan $100^{\circ} \mathrm{C}$. Selama penyangraian terdapat beberapa bahan aktif yang mengalami kerusakan pada suhu tinggi seperti senyawa fenol yang memiliki rentang suhu optimal $0^{\circ} \mathrm{C}-90^{\circ} \mathrm{C}$ (Putri et al., 2014). Hal itu menyebabkan perlakuan penyangraian suhu $90^{\circ} \mathrm{C}$ dan $100^{\circ} \mathrm{C}$ waktu selama 15 menit kandungan dari total fenol kopi tiruan biji pepaya menurun.

\section{Total Flavonoid}

Nilai rata-rata total flavonoid kopi tiruan biji pepaya dengan perlakuan suhu dan waktu penyangraian dapat dilihat pada Tabel 4

Tabel 4. Nilai rata-rata total flavonoid (mgQE/g) kopi tiruan biji pepaya dengan perlakuan suhu dan waktu penyangraian

\begin{tabular}{cccc}
\hline Suhu & \multicolumn{3}{c}{ Waktu Penyangraian } \\
\cline { 2 - 4 } Penyangraian & L1 (5 Menit) & L2 $(10$ Menit $)$ & L3 (15 Menit) \\
\hline T1 $\left(80^{\circ} \mathrm{C}\right)$ & $0,21 \pm 0,00 \mathrm{~b}$ & $0,22 \pm 0,00 \mathrm{c}$ & $0,22 \pm 0,00 \mathrm{c}$ \\
& $(\mathrm{a})$ & $(\mathrm{a})$ & (a) \\
$\mathrm{T} 2\left(90^{\circ} \mathrm{C}\right)$ & $0,22 \pm 0,00 \mathrm{~b}$ & $0,23 \pm 0,01 \mathrm{~b}$ & $0,23 \pm 0,01 \mathrm{~b}$ \\
& $(\mathrm{a})$ & $(\mathrm{a})$ & (a) \\
$\mathrm{T} 3\left(100^{\circ} \mathrm{C}\right)$ & $0,25 \pm 0,01 \mathrm{a}$ & $0,29 \pm 0,01 \mathrm{a}$ & $0,28 \pm 0,00 \mathrm{a}$ \\
& $(\mathrm{b})$ & (a) & (a) \\
\hline
\end{tabular}

Keterangan: Nilai rata-rata \pm standar deviasi. Huruf yang sama dibelakang nilai rata-rata pada kolom yang sama dan dibawah nilai rata-rata pada baris yang sama menunjukkan berbeda tidak nyata $(\mathrm{P}>0,05)$.

Hasil sidik ragam menunjukkan bahwa interaksi antara suhu dan waktu penyangraian berpengaruh nyata $(\mathrm{P}<0,05)$ terhadap total flavonoid kopi tiruan biji pepaya. Hasil penelitian menunjukkan total flavonoid biji pepaya segar yaitu sebesar 0,23 $\mathrm{mgQE} / \mathrm{g}$. Nilai rata-rata total flavonoid kopi tiruan biji pepaya berkisar antara 0,21 - 0,29 mgQE/g dengan total flavonoid terendah yaitu T1L1 sebesar 0,21 $\mathrm{mgQE} / \mathrm{g}$ dan total flavonoid tertinggi yaitu T3L2 sebesar 0,29 mgQE/g (Tabel 4).

Suhu dan waktu penyangraian berpengaruh signifikan terhadap total flavonoid kopi tiruan biji pepaya. Pada perlakuan T1L1, T1L2, T1L3, T2L1 dan T2L2 total flavonoid terus meningkat dan mengalami penurunan kembali pada perlakuan T2L3 dan T3L3. Perlakuan T1L1 menghasilkan total fenol terendah yaitu sebesar $0,21 \mathrm{mgQE} / \mathrm{g}$. Hal ini bisa disebabkan karena rendahnya suhu dan waktu yang digunakan pada saat proses penyangraian, sehingga senyawa-senyawa yang terdapat pada biji pepaya belum terurai secara sempurna. Ketahanan optimal pada senyawa flavonoid memiliki rentang suhu $0^{\circ} \mathrm{C}-$ $100^{\circ} \mathrm{C}$ (Putri et al., 2014). Hal itu menyebabkan perlakuan penyangraian suhu $100^{\circ} \mathrm{C}$ waktu selama 15 
menit kandungan dari total flavonoid biji pepaya menurun.

\section{Aktivitas Antioksidan}

Nilai rata-rata aktivitas antioskidan kopi tiruan biji pepaya dengan perlakuan suhu dan waktu penyangraian dapat dilihat pada Tabel 5 .

Hasil sidik ragam menunjukkan bahwa interaksi antara suhu dan waktu penyangraian berpengaruh nyata $(\mathrm{P}<0,05)$ terhadap aktivitas antioksidan kopi tiruan biji pepaya. Hasil penelitian menunjukkan aktivitas antioksidan biji pepaya segar yaitu sebesar 41,85\%. Nilai rata-rata aktivitas antioksidan kopi tiruan biji pepaya berkisar antara 19,88 - 39,06\% dengan nilai aktivitas aktioksidan terendah yaitu T3L3 sebesar 19,88\% dan nilai aktivitas antioksidan tertinggi yaitu T1L3 sebesar 39,06\% (Tabel 5). Perlakuan T3L3 menghasilkan nilai aktivitas antioksidan terendah yaitu sebesar 19,88\%. Hal ini disebabkan karena total fenol dan total flavonoid pada perlakuan suhu $90^{\circ} \mathrm{C}$ mengalami peningkatan, namun pada perlakuan suhu $100^{\circ} \mathrm{C}$ dengan waktu $10-15$ menit aktivitas antioksidan mengalami penurunan kembali pada perlakuan waktu penyangraian yang semakin lama dan suhu yang semakin tinggi. Senyawa antioksidan akan mudah terdegradasi jika terkena suhu tinggi dalam waktu yang lama. Hal ini dikarenakan senyawa antioksidan kehilangan kemampuan mendonorkan elektron untuk menetralkan senyawa-senyawa radikal (Patras et al., 2009). Semakin tinggi kadar total fenol dan flavonoid maka semakin tinggi kemampuan antioksidan dalam mendonorkan elektronnya dalam hal menekan perkembangan radikal bebas. Komponen fenolik ataupun flavonoid merupakan senyawa utama dalam peranan antioksidan (Al-Farsi et al., 2007).

Tabel 5. Nilai rata-rata aktivitas antioksidan (\% bb) kopi tiruan biji pepaya dengan perlakuan suhu dan waktu penyangraian

\begin{tabular}{|c|c|c|c|}
\hline \multirow{2}{*}{$\begin{array}{c}\text { Suhu } \\
\text { Penyangraian }\end{array}$} & \multicolumn{3}{|c|}{ Waktu Penyangraian } \\
\hline & L1 (5 Menit) & L2 (10 Menit) & L3 (15 Menit) \\
\hline $\mathrm{T} 1\left(80^{\circ} \mathrm{C}\right)$ & $\begin{array}{c}30,05 \pm 0,80 \mathrm{a} \\
\text { (a) }\end{array}$ & $\begin{array}{c}32,73 \pm 1,10 \mathrm{a} \\
\text { (a) }\end{array}$ & $\begin{array}{c}39,06 \pm 4,70 \mathrm{a} \\
\text { (a) }\end{array}$ \\
\hline $\mathrm{T} 2\left(90^{\circ} \mathrm{C}\right)$ & $\begin{array}{c}25,18 \pm 0,82 b \\
(a b)\end{array}$ & $\begin{array}{c}30,50 \pm 3,17 \mathrm{a} \\
\text { (a) }\end{array}$ & $\begin{array}{c}23,14 \pm 0,68 \mathrm{~b} \\
\text { (b) }\end{array}$ \\
\hline $\mathrm{T} 3\left(100^{\circ} \mathrm{C}\right)$ & $\begin{array}{c}22,83 \pm 0,56 \mathrm{c} \\
\text { (a) }\end{array}$ & $\begin{array}{c}24,03 \pm 0,87 \mathrm{~b} \\
\text { (a) }\end{array}$ & $\begin{array}{c}19,88 \pm 0,85 b \\
\text { (b) }\end{array}$ \\
\hline
\end{tabular}

Keterangan: Nilai rata-rata \pm standar deviasi. Huruf yang sama dibelakang nilai rata-rata pada kolom yang sama dan dibawah nilai rata-rata pada baris yang sama menunjukkan berbeda tidak nyata $(\mathrm{P}>0,05)$. 


\section{Uji Kualitatif Kafein Kopi Tiruan Biji Pepaya}

Hasil uji kafein secara kualitatif kopi biji pepaya dengan perlakuan suhu dan waktu penyangraian dapat dilihat pada Tabel 6 .

Hasil penelitian menunjukkan bahwa kopi tiruan biji pepaya setelah ditambahkan reagen Parry tidak ada yang berwarna hijau lumut (Tabel 6). Hal ini menunjukkan bahwa pada kopi biji pepaya tidak mengandung kafein. Hal ini sesuai dengan penelitian yang dilakukan oleh Erlinda dan Fenti (2015) biji pepaya dapat diolah menjadi minuman kopi non kafein yang baik untuk kesehatan terutama dalam pengobatan hiperlipidemia. Kopi merupakan salah satu dari beberapa bahan alam yang mengandung kafein, hasil pengujian kualitatif pada penelitian ini menunjukkan bahwa semua sampel negatif mengandung kafein

Tabel 6. Hasil uji kafein secara kualitatif kopi biji pepaya dengan perlakuan suhu dan waktu penyangraian

\begin{tabular}{ccl}
\hline Perlakuan & \multicolumn{1}{c}{ Warna } & Kafein \\
& Hasil Uji Kualitatif & \\
\hline T1L1 & Putih kecokelatan & Negatif \\
T2L1 & Putih kecokelatan & Negatif \\
T3L1 & Putih kecokelatan & Negatif \\
T1L2 & Kuning kecokelatan & Negatif \\
T2L2 & Kuning kecokelatan & Negatif \\
T3L2 & Merah kecokelatan & Negatif \\
T1L3 & Merah kecokelatan & Negatif \\
T2L3 & Cokelat kehitaman & Negatif \\
T3L3 & Cokelat kehitaman & Negatif \\
\hline
\end{tabular}

Keterangan: Warna hijau lumut yang dihasilkan setelah ditambahkan reagen Parry menunjukkan adanya kandungan kafein pada bahan, apabila warna yang dihasilkan selain dari hijau lumut menunjukkan bahwa tidak adanya kandungan kafein (negatif)

\section{Sifat Sensoris Kopi Tiruan Biji Pepaya}

Sifat sensoris kopi tiruan biji pepaya ini dilakukan dengan uji skoring terhadap warna, aroma, dan rasa serta uji hedonik penerimaan keseluruhan. Nilai rata-rata uji skoring terhadap warna, aroma dan rasa kopi tiruan biji pepaya dengan perlakuan suhu dan waktu penyangraian dapat dilihat pada tabel 7 dan uji hedonik terhadap penerimaan keseluruhan kopi tiruan biji pepaya dengan perlakuan suhu dan waktu penyangraian dapat dilihat pada Tabel 8 .

\section{Warna Kopi Biji Pepaya}

Hasil sidik ragam menunjukkan bahwa interaksi antara suhu dan waktu penyangraian berpengaruh nyata $(\mathrm{P}<0,05)$ terhadap warna kopi tiruan biji pepaya (uji skoring). Tabel 7 menunjukkan penerimaan terhadap warna kopi tiruan biji pepaya terendah adalah pada perlakuan T1L1, T2L1, dan T3L1 yaitu 1,00 (putih kecokelatan) dan tertinggi adalah pada perlakuan T3L3 yaitu 4,92 (cokelat kehitaman). Hal ini sangat dipengaruhi oleh suhu dan waktu penyangraian. Perlakuan T3L3 
merupakan perlakuan yang warnanya paling disukai oleh panelis karena menghasilkan warna kopi yang tepat yaitu cokelat kehitaman. Perubahan warna menjadi cokelat kehitaman terjadi akibat perubahan senyawa hidrokarbon antara lain karbohidrat, hemiselulosa, dan selulosa yang ada di dalam biji akibat pemanasan atau dikenal dengan pirolisis. Peristiwa pirolisis pada kopi umumnya terjadi pada suhu $250^{\circ} \mathrm{C}$, akan tetapi jika melihat dari karakteristik biji pepaya yang lebih tipis dan ukurannya lebih kecil mungkin proses ini bisa terjadi pada suhu $100^{\circ} \mathrm{C}$ sehingga menghasilkan warna cokelat kehitaman.

Hasil sidik ragam menunjukkan bahwa interaksi antara suhu dan waktu penyangraian berpengaruh nyata $(\mathrm{P}<0,05)$ terhadap rasa kopi tiruan biji pepaya (uji skoring). Tabel 7 menunjukkan penerimaan terhadap rasa kopi biji pepaya terendah adalah pada perlakuan T1L1 dan T2L1 yaitu 2,92 (agak pahit) dan tertinggi adalah pada perlakuan T3L3 yaitu 4,96 (sangat pahit). Panelis menyatakan bahwa semakin tinggi suhu dan waktu penyangraian maka rasa kopi tiruan biji pepaya semakin pahit. Berdasarkan hasil uji sensoris terhadap rasa kopi biji pepaya menunjukkan bahwa tingkat penerimaan panelis ratarata 2,92-4,96 artinya sudah pada taraf rasanya pahit. Selama penyangraian terjadi pembentukan senyawa organik yang dihasilkan dari pirolisis. Peristiwa pirolisis pada kopi umumnya terjadi pada suhu $250^{\circ} \mathrm{C}$, akan tetapi jika melihat dari karakteristik biji pepaya yang lebih tipis dan ukurannya lebih kecil mungkin proses ini bisa terjadi pada suhu $100^{\circ} \mathrm{C}$ sehingga menghasilkan rasa kopi biji pepaya yang pahit. Hal ini sesuai dengan penelitian yang dilakukan oleh Mulato (2002).

Tabel 7. Nilai rata-rata uji warna, aroma dan rasa kopi tiruan biji pepaya dengan perlakuan suhu dan waktu penyangraian

\begin{tabular}{cccc}
\hline Perlakuan & Warna (Skoring) & Aroma (Skoring) & Rasa (Skoring) \\
\hline T1L1 & $1,00 \pm 0,00 \mathrm{f}$ & $5,00 \pm 0,00 \mathrm{a}$ & $2,92 \pm 0,28 \mathrm{c}$ \\
T2L1 & $1,00 \pm 0,00 \mathrm{f}$ & $5,00 \pm 0,00 \mathrm{a}$ & $2,92 \pm 0,28 \mathrm{c}$ \\
T3L1 & $1,00 \pm 0,00 \mathrm{f}$ & $5,00 \pm 0,00 \mathrm{a}$ & $3,04 \pm 0,20 \mathrm{c}$ \\
T1L2 & $1,04 \pm 0,20 \mathrm{f}$ & $4,12 \pm 0,33 \mathrm{~b}$ & $3,16 \pm 0,28 \mathrm{c}$ \\
T2L2 & $2,32 \pm 0,48 \mathrm{e}$ & $4,00 \pm 0,00 \mathrm{c}$ & $3,08 \pm 0,40 \mathrm{c}$ \\
T3L2 & $3,00 \pm 0,00 \mathrm{~d}$ & $4,00 \pm 0,00 \mathrm{c}$ & $4,08 \pm 0,28 \mathrm{~b}$ \\
T1L3 & $3,72 \pm 0,46 \mathrm{c}$ & $3,00 \pm 0,00 \mathrm{~d}$ & $4,00 \pm 0,29 \mathrm{~b}$ \\
T2L3 & $4,00 \pm 0,00 \mathrm{~b}$ & $3,00 \pm 0,00 \mathrm{~d}$ & $4,80 \pm 0,70 \mathrm{a}$ \\
T3L3 & $4,92 \pm 0,28 \mathrm{a}$ & $3,00 \pm 0,00 \mathrm{~d}$ & $4,96 \pm 0,20 \mathrm{a}$ \\
\hline
\end{tabular}

Keterangan : Nilai rata-rata yang diikuti oleh huruf yang sama pada kolom yang sama menunjukkan berpengaruh tidak nyata $(\mathrm{P}>0,05)$.

Kriteria skoring warna: 1 (putih kecokelatan), 2 (kuning), 3 (cokelat kekuningan), 4 (cokelat kemerahan), 5 (cokelat kehitaman).

Kriteria skoring rasa: 1 (sangat tidak pahit), 2 (tidak pahit), 3 (agak pahit), 4 (pahit), 5 (sangat pahit).

Kriteria skoring aroma: 1 (sangat tidak khas kopi biji pepaya), 2 (tidak khas kopi biji pepaya), 3 (agak khas kopi biji pepaya), 4 ( khas kopi biji pepaya), 5 (sangat khas kopi biji pepaya. 
Tabel 8. Nilai rata-rata uji hedonik penerimaan keseluruhan kopi tiruan biji pepaya dengan perlakuan suhu dan waktu penyangraian

\begin{tabular}{cc}
\hline Perlakuan & Warna (Skoring) \\
\hline T1L1 & $2,80 \pm 0,96 \mathrm{~d}$ \\
T2L1 & $3,72 \pm 0,80 \mathrm{c}$ \\
T3L1 & $3,96 \pm 0,54 \mathrm{c}$ \\
T1L2 & $4,92 \pm 0,76 \mathrm{~b}$ \\
T2L2 & $5,08 \pm 0,28 \mathrm{~b}$ \\
T3L2 & $6,24 \pm 0,72 \mathrm{a}$ \\
T1L3 & $6,80 \pm 0,41 \mathrm{a}$ \\
T2L3 & $5,04 \pm 0,46 \mathrm{~b}$ \\
T3L3 & $5,12 \pm 0,83 \mathrm{~b}$ \\
\hline
\end{tabular}

Keterangan : Nilai rata-rata yang diikuti oleh huruf yang sama pada kolom yang sama menunjukkan berpengaruh tidak nyata $(\mathrm{P}>0,05)$

Kriteria skoring rasa: 1 (sangat tidak suka), 2 (tidak suka), 3 (agak tidak suka), 4 (biasa), 5 (agak suka), 6 (suka), 7

(sangat suka)

\section{Rasa Kopi Tiruan Biji Pepaya}

Hasil sidik ragam menunjukkan bahwa interaksi antara suhu dan waktu penyangraian berpengaruh nyata $(\mathrm{P}<0,05)$ terhadap rasa kopi tiruan biji pepaya (uji skoring). Tabel 7 menunjukkan penerimaan terhadap rasa kopi biji pepaya terendah adalah pada perlakuan T1L1 dan T2L1 yaitu 2,92 (agak pahit) dan tertinggi adalah pada perlakuan T3L3 yaitu 4,96 (sangat pahit). Panelis menyatakan bahwa semakin tinggi suhu dan waktu penyangraian maka rasa kopi tiruan biji pepaya semakin pahit. Berdasarkan hasil uji sensoris terhadap rasa kopi biji pepaya menunjukkan bahwa tingkat penerimaan panelis rata-rata 2,92-4,96 artinya sudah pada taraf rasanya pahit. Selama penyangraian terjadi pembentukan senyawa organik yang dihasilkan dari pirolisis. Peristiwa pirolisis pada kopi umumnya terjadi pada suhu $250^{\circ} \mathrm{C}$, akan tetapi jika melihat dari karakteristik biji pepaya yang lebih tipis dan ukurannya lebih kecil mungkin proses ini bisa terjadi pada suhu $100^{\circ} \mathrm{C}$ sehingga menghasilkan rasa kopi biji pepaya yang pahit. Hal ini sesuai dengan penelitian yang dilakukan oleh Mulato (2002), semakin lama penyangraian maka cita rasa khas kopi sangrai semakin terbentuk. Menurut Winarno (2008), rasa merupakan salah satu faktor mutu yang dapat mempengaruhi suatu produk pangan. Reaksi Mailard yang terjadi selama penyangraian akan mempengaruhi warna dan cita rasa kopi. Rasa yang enak dapat menunjang produk diterima oleh konsumen, dan menurut panelis rasa dari perlakuan T3L3 sudah memiliki cita rasa kopi biji pepaya yang diinginkan.

\section{Aroma Kopi Tiruan Biji Pepaya}

Hasil sidik ragam menunjukkan bahwa interaksi antara suhu dan waktu penyangraian berpengaruh nyata $(\mathrm{P}<0,05)$ terhadap aroma kopi tiruan biji pepaya (uji skoring). Tabel 7 menunjukkan penerimaan terhadap aroma kopi tiruan biji pepaya terendah pada perlakuan T1L3, T2L3 dan T3L3 yaitu 
3,00 (agak khas kopi tiruan biji papaya) dan tertinggi adalah pada perlakuan T1L1, T2L1 dan T3L1 yaitu 5,00 (sangat khas kopi tiruan biji papaya). Hal ini disebabkan oleh suhu dan waktu penyangraian yang digunakan. Aroma biji papaya yang kuat akan menghasilkan kopi tiruan biji papaya dengan aroma yang khas kopi biji papaya. Ummah (2012) melaporkan bahwa biji pepaya memiliki aroma yang sangat tajam dan khas.

\section{Penerimaan Keseluruhan Kopi Tiruan Biji Pepaya}

Hasil sidik ragam menunjukkan bahwa interaksi antara suhu dan waktu penyangraian berpengaruh nyata $(\mathrm{P}<0,05)$ terhadap penerimaan keseluruhan kopi biji pepaya (uji hedonik). Tabel 8 menunjukkan penerimaan terhadap penerimaan keseluruhan kopi biji pepaya terendah adalah pada perlakuan T1L1 yaitu 2,80 (agak tidak suka) dan tertinggi adalah pada perlakuan T1L3 yaitu 6,80 (sangat suka). Penerimaan keseluruhan kopi biji pepaya dipengaruhi oleh beberapa faktor seperti warna, rasa dan aroma.

\section{KESIMPULAN DAN SARAN}

\section{Kesimpulan}

Suhu dan waktu penyangraian berpengaruh terhadap kadar total fenol, kadar flavonoid, aktivitas antioksidan, warna, rasa, aroma dan penerimaan keseluruhan. Perlakuan suhu penyangraian $100^{\circ} \mathrm{C}$ dengan waktu penyangraian 10 menit menghasilkan kopi biji pepaya dengan karakteristik terbaik dengan kadar air 3,76\%, total fenol $1,25 \mathrm{mgGAE} / \mathrm{g}$, total flavonoid 0,29 $\mathrm{mgQE} / \mathrm{g}$, aktivitas antioksidan
24,03\%, warna hasil uji kualitatif kafein merah kecokelatan/negatif, dengan warna cokelat kekuningan, aroma khas kopi biji pepaya, rasa pahit, dan penerimaan keseluruhan suka.

\section{Saran}

Perlu dilakukan penelitian lebih lanjut mengenai penambahan bahan lain untuk mendapatkan nilai uji bioaktif dan evaluasi sensoris yang lebih tinggi.

\section{UCAPAN TERIMAKASIH}

Ucapan terima kasih kepada Balai Penelitian Tanaman Industri dan Penyegar (BALITTRI) serta semua pihak yang telah membantu dalam penyelesaian penelitian ini.

\section{DAFTAR PUSTAKA}

Agustina, D., dan R. Hesti. 2013. Pengaruh Pemberian Jus Biji Pepaya (Carica papaya, L.) Terhadap Rasio Kolesterol LDL : HDL Tikus Sprague Dawley Dislipedemia. Tesis S2. Fakultas Kedokteran Universitas Diponegoro, Semarang.

Al-Farsi, M., dan F. Al-Rawahy. 2007. Compositional and Functional Characteristics of Dates, Syrups, and their By-Products. Food Chemistry. 943-947.

Wahyu, A. 2002. Resep Ramuan Herbal Berkhasiat Untuk Cantik Alami. PT Gramedia Pustaka Utama. Jakarta.

Andriani, Y. Y., L Rahmiyani., S. Amin., dan T. Lestari. 2016. Kadar Fenol Total Ekstrak Daun dan Biji Pepaya (Carica Papaya L) Menggunakan Metode Spektrofotometri Uv-Vis. Jurnal Kesehatan Bakti Tunas Husada, Tasikmalaya. 15(1).

Annisa. 2016. Uji Karakteristik Kopi Non Kafein Dari Biji Pepaya Dengan Variasi Lama Penyinaran. Skripsi. Program Studi Teknologi Hasil Pertanian. Politeknik Gorontalo.

Anonimus. 1992. SNI 01-2983-1992. Kopi Instan. Badan Standar Nasional, Jakarta.

Anonimus. 2004. SNI 3542:2004. Kopi Bubuk. Badan Standar Nasional, Jakarta. 
Bactiar, A., A. Ali dan E. Rossi. 2017. Pembuatan Permen Jelly Ekstrak Jahe Merah Dengan Penambahan Karagenan. JOM Faperta, Universitas Riau. 4(1): 1-13

Erlinda dan Fenti. 2015. Kopi Bubuk Biji Pepaya Sebagai Alternatif Pengobatan Hiperlipidemia, Ekonomis dan Berdaya Saing Pada MEA 2015. Karya Tulis Ilmiah dalam LKTI Nasional. Malang.

Estiasih dan Ahmadi. 2009. Teknologi Pengolahan Pangan. PT. Bumi Aksara. Jakarta. 236-237.

Gardjito dan Rahardian. 2011. Pengaruh Berbagai Metode Penyeduhan Dua Jenis Kopi Bubuk Terhadap Kadar Kafein dan Aktivitas Antioksidan dalam Minuman Kopi. Jurnal Fakultas Teknologi Pertanian. Universitas Andalas.

Gomez, K. A. dan A. A Gomez. 1995. Prosedur Statistika untuk Penelitian Pertanian (Terjemahan: Endang Sjamsuddin dan Justika S. Baharsjah). UI Press, Jakarta.

Hamni dan Arinal. 2014. Implementasi Sistem Gasifikasi untuk Pengeringan Biji Kopi. Jurnal Mechanical. Universitas Lampung. 5(1).

Hanani, E. A., Mun'im dan E. Sekarini. 2005. Identifikasi Senyawa Antioksidan dalam Spons Callyspongia sp. dari Kepulauan Seribu. Majalah Ilmu Kefarmasian. Fakultas MIPA UI. Depok. 2(3):127-133.

Ibrahim, A.M., Yuanianta, dan F.H. Sriherfyna. 2015. Pengaruh Suhu dan Lama Waktu Ekstraksi Terhadap Sifat Kimia dan Fisik Pada Pembuatan Minuman Sari Jahe Merah (Zingiber Officinale Var. Rubrum) dengan Kombinasi Penambahan Madu Sebagai Pemanis. Jurnal Pangan dan Agroindustri. Universitas Brawijaya, Malang. 3(2):530-541.

Maramis, R. K., G. Citraningtyas dan F. Wehantouw, 2013. Analisis Kafein dalam Kopi Bubuk di Kota Manado Menggunakan Spektrofotometri Uv-Vis. Jurnal Ilmiah Farmasi UNSRAT, Manado. 2(4):122-128.

Mariati. 2015. Optimasi Pembuatan Kopi Biji Pepaya. Jurnal Teknologi Agroindustri. Politeknik Negeri Tanah Laut. Kalimantan Selatan. 2(2).

Mulato, S. 2002. Mewujudkan Perkopian Nasional yang Tangguh Melalui Diversifikasi Usaha Berwawasan Lingkungan Dalam Pengembangan Industri Kopi Bubuk Skala Kecil Untuk Meningkatkan Nilai Tambah Usaha Tani Kopi Rakyat. Simposium Kopi Pusat Penelitian Kopi dan Kakao Indonesia.
Nindyasari. 2012. Pengaruh Suhu dan Waktu Penyeduhan Teh Hijau (Camellia sinensis) Serta Proses Pencernaan in Vitro Terhadap Aktivitas Inhibisi Lipase. Skripsi. Insitut Pertanian Bogor. Bogor.

Nugroho, J. 2009. Pengaruh Suhu dan Lama Penyangraian Terhadap Sifat Fisik Mekanis Kopi Robusta. Makalah Bidang Produk Pertanian. Universitas Gadjah Mada. Yogyakarta.

Ogita, S., H. Uefuji. 2003. Producing Decaffeinated coffe plants. Nature 423:823

Putri, D.D., D.E. Nurmagustina, dan A.A. Chandra. 2014. Kandungan Total Fenol dan Aktivitas Antibakteri Kelopak Buah Rosela Merah dan Ungu Sebagai Kandidat Feed Additive Alami Pada Broiler. Jurnal Penelitian Pertanian Terapan. Politeknik Negeri Lampung. Lampung. 14(3):174180.

Rahman, A., Riyanto dan Utari. 2006. Aktivitas Antioksidan, Kandungan Fenolat Total dan Kandungan Flavonoid Total Ekstrak Etil Asetat Buah Mengkudu Serta Fraksi-Fraksinya. Majalah Farmasi Indonesia. 17:137-13.

Sakanaka, S., Y. Tachibana, Okada, dan Yuki. 2003. Perparation and Antioxidant Poperties of Ekstract of Japanese Persimo Leaf Tea (Kakinocha-cha). Food chemistry $89: 569-575$.

Soekarto. 1985. Penilaian Organoleptik untuk Industri Pangan dan Hasil Pertanian. Pusat Pengembangan Teknologi Pangan, IPB, Bogor.

Sudarmadji, S., B. Haryono dan Suhardi. 1997. Prosedur Analisa Untuk Bahan Makanan Dan Pertanian. Liberty, Yogyakarta.

Ummah, W. 2012. Pengaruh Ekstrak Air Biji Pepaya (Carica papaya L.) dan Testosteron Undekanoat (TU) Terhadap Jaringan Ginjal Mencit (Mus musculus, L.). Skripsi S1 FMIPA Universitas Sumatera Utara. Medan.

Utami, R. 2016. Aktivitas Antioksidan Kulit Biji Kakao dari Hasil Penyangraian Biji Kakao Kering pada Derajat Ringan, Sedang dan Berat. Jurnal Agritech. Universitas Gadjah Mada. Yogyakarta. 37(1):88-94.

Wazir, D., S. Ahmad., R. Muse., M. Mahmood., M.Y. Shukor. 2011. Antioxidant Activities of Different Parts of Gnetum gnemon L. Journal Plant Biochemistry and Biotechnology. 20(2):234-240.

Winarno, F.G. 1992. Kimia Pangan dan Gizi. PT. Gramedia Pustaka, Jakarta. 